\title{
Influence of licopine content in tomatoes on taste qualities of canned goods
}

\author{
(C) Saida S. Saidova \\ Dagestan State Technical University. Imam Shamil Ave., 70 A. \\ Makhachkala, 367026. Republic of Dagestan. Russia.
}

Keywords: biotechnology, tomato fruits, lycopene, functional foods, heat treatment technology, quality of canned food.

\begin{abstract}
The article provides a review of world data on the characteristics of the chemical composition of tomato fruits and the impact on their quality of the soil and climatic conditions of cultivation, varietal characteristics and maturity. It is noted that the current regulatory and technical documentation in the Russian Federation does not provide for the determination of functional substances. It has been shown that tomato fruits are a promising plant-growing raw material for the production of functional food products and directions for obtaining lycopene-containing products, canned foods, in particular, from tomato fruits, have been determined. The types of canned food and tomato products containing the highest concentrations of lycopene have been established. The regularity of increasing the concentrations of lycopene in tomato products with various methods of heat treatment is substantiated. The irreplaceable physiological significance of lycopene for the human body is proved, due to its antioxidant properties and the lack of the possibility of its synthesis. The biochemical nature of lycopene as a carotenoid and pigment is analyzed. The progressive foreign technologies of tomato processing have been studied, allowing to reduce the economic costs of production, increase the duration of storage of products containing extremely high concentrations of lycopene. The necessity of developing domestic food products of physiological importance, available for consumption in baby and diet food, is substantiated. It is proved that the Republic of Dagestan has a high climatic and resource potential for growing hybrid varieties of tomatoes containing high concentrations of lycopene and the mass fraction of dry matter necessary for the rational production of canned tomatoes.
\end{abstract}

\section{References}

[1] S. Furuta, Y. Nishiba, J. Suda. Flurometric assay for sereening antioxidative activity of vegetables. $J$. Food Sci. 2002. Vol.62. No.3. P.526-528.

[2] G. Muratore, F. Licciardello, E.J. Maccarone. Evaluation of the chemical quality of a new type of small-sized tomato cultivar, the plum tomato (Lycopercicon licopersicum). Food Sci. 2015. Vol.17. No.1. P.75-81.

[3] E. Giovannucci, E.B. Rimm, Y. Liu, M.J. Stampfer, W.C. Willett. A prospective study of tomato products, lycopene, and prostate cancer risk. J Natl Cancer Inst. 2002. Vol.94. No.5. P.391-398.

[4] Heber D. and Qing-Yi Lu. Overview of Mechanisms of Action of Lycopene. Experemental Bio and Med. 2012. Vol.227. No.10. P.920-923.

[5] David Heber, Qing-Yi Lu. Overview of Mechanisms of Action of Lycopene. First Published November 1, 2002. Vol.227. Iss.10. P.920-923.

[6] J.K. Campbell, K. Canene-Adams, B.L. Lindshield, T.W.M. Boileau, S.K. Clinton. Tomato phytochemicals and prostate cancer risk. Journal of nutrition. 2016. Vol.134. No.12. P.411-416.

[7] Lycopene and Beta-carotene Induce Cell-Cycle Arrest and Apoptosis in Human BreastCancer Cell Lines. Nathalie Fonseca Gloria, Nathalie Soares, Camila Brand, Felipe Leite Oliveira, Radovan Borojevic and Anderson Junger Teodoro. Anticancer Research. 2014. Vol.34. P.1377-1386.

[8] G. Britton. Biochemistry of natural pigments: trans. from English. Moscow: Mir. 2016. 422p. (russian)

[9] Crop production. Statistical collection of State statistics of the Russian Federation. Moscow. 2019. 166p. (russian)

[10] Assessment of the quality of fresh tomatoes by color and hardness: [trans. from English.] / Edano Jarl [and others.]. J. Food Sci. 2007. No.4. P.793-796.

[11] Schindler Mickaela. Phenolik compounds in tomatoes. Natural variations and effect of gammairradiation. M. Schindler, S. Solar, G. Sontag [Institute for Analytical Chemistry, University of Vienna]. Eur. Food Res. And Technol. 2005. No.3-4. P.439-445. 
[12] M. Hernandez Suarez, E. M. Rodriguez Rodriguez, C. Diaz Romero. Mineral and trace element concentrations in cultivates of tomatoes. Food Chem. 2007. No.2. P.489-499.

[13] G.M. Smirnov, S.D. Bazilevich, V.A. Rakipova, L.V. Obukhovskaya. Accumulation of nitrates by certain vegetable and feed crops at equal levels of nitrogen nutrition. Quality of the fetus. and bakhchev. cultures. 2018. P.128-132. (russian)

[14] S.F. Gavrish, S.N. Galkina. Tomato: processing and processing of products. Food. 2005. No.5. P.15-18. (russian)

[15] A.V. Skripko, I.A. Kadnikova, V.V. Sedykh. Justification of the parameters of the process of obtaining a protein-lipid product for food concentrates. Technique and technology of food production. 2012. No.1. P.104-108. (russian)

[16] T.W. Goodwin, M. Jamikorn. Biosynthesic of carotenes in ripening tomatoes. Nature 170. 2012. No.4316. P.104-105.

[17] V.K. Andryushchenko, D.A. Vyrodova, A.P. Vyrodova, A.F. Mugniev. Evaluation and selection of high carotene forms of tomato and carrot. Methodical instructions of the Lenin All-Union Academy of Agricultural Sciences (VASKHNIL). Moscow. 2011. 56p. (russian)

[18] S. Devaraj [et al.]. A dose-response study on the effects of purified lycopene supplementation on biomarkers of oxidative stress. J. Am. Coll. Nutr. 2008. No.27(2). P.267-273.

[19] A.I. Dragilev, I.S. Lurie. Technology of confectionery Text. Moscow: DeLi-Print. 2003. P.430-435. (russian)

[20] V.N. Karnaukhov. The function of carotenoids is an object of biological research. Biophysics. 2010. Vol.45. No.2. P.364-384. (russian)

[21] Guide to gerontology and geriatrics. ed. Acad. RAMS, prof. V.N. Yarygin, prof. Ya.S. Melentieva. Moscow: GEOTAR-Media. 2010. 720p. (russian)

[22] G.I. Klebanov, O.B. Lyubitsky, S.E. Ilyina, E.A. Medusheva, V.V. Ryltsev, V.N. Filatov. Antioxidant activity of inhibitors of free radical reactions used in dressings for the treatment of wounds. Biomedical chemistry. 2006. No.1. P.69-81. (russian)

[23] G.R. Takeoka [et al.]. The influence of technological processing on the content of lycopene and its antioxidant activity in tomatoes. J. Agr. and Food Chem. 2001. Iss.49. No.8. P.3713-3717.

[24] A.S. Bolotskikh. Tomatoes. Kharkov: Folio. 2013. 318p.

[25] V.N. Podobed. Modern antioxidant therapy. News of examination and registration. 2007. No.10. P.48-51.

[26] GOST 1725-85 "Fresh tomatoes. Technical conditions" (with Amendments No. 1, 2, 3) [Electronic resource]. Access mode: http://docs.cntd.ru/document/1200006123. Date of appeal: 03.30.2020. 